\title{
Lactic acid bacteria compositions for application in the meat industry
}

\section{Lyudmila Vinnikova ${ }^{1}$, Andrey Kishenya ${ }^{1}$, Irina Strashnova ${ }^{2}$}

\author{
1 - Odesa National Academy of Food Technologies, Odesa, Ukraine \\ 2 - Odesa I.I. Mechnikov National University, Odesa, Ukraine
}

Keywords:

Meat

Lactic acid

Bacteria

Halo-resistance

Thermo-resistance antagonism

Article history:

Received 14.03.2016

Received in revised

form 15.05 .2016

Accepted 30.06.2016

\section{Corresponding}

author:

Andrey Kishenya

E-mail:

andrey.kishenya@

mail.ru

\section{Abstract}

Introduction. Despite a large number of the bacterial preparations used in the meat industry, development of new starters and study of their influence on development of undesirable microbiota are still vital.

Materials and methods. We studied the halo- and thermoresistance of 8 collection strains of the lactic acid bacteria and the compositions made of these lactic acid bacteria. The antagonistic activity toward the indicator strains, isolated from the raw meat, and the collection bacteria strains was determined by the well-diffusion method.

Results and discussion. At the maximum $\mathrm{NaCl}$ concentration $(10.0 \%)$ in the growing medium, the strains of L. plantarum 12 and 1005 were characterized by high growth rate, L. delbrueckii $s / s p$. lactis 013 and $L$. casei $s / s p$. tolerans 290 - by the average one. Thermo-resistant (that is able to grow quickly at the temperature ranged from 5 to $25{ }^{\circ} \mathrm{C}$ ) were the strains of $L$. plantarum $12, L$. delbrueckii s/sp.lactis 013, L. acidophilus 147 and L. casei s/sp. tolerans 187 and 290. The lactic acid bacteria showed the antagonistic activity to both, the strains isolated from the raw meat, and the collection strains of bacteria. Growth of some indicator bacteria was slowed down only, while that of others - completely inhibited. The best antagonists were the strains of L. plantarum 12, L. delbrueckii s/sp. lactis 013 and L. casei s/sp. tolerans 290, which completely inhibited the growth of Bacillus sp. 3, Kurthia sp., Planacoccus sp. 1, sp. 2, Micrococcus sp. 2, Sarcina sp. and Staphylococcus $s p$., isolated from meat and the collection bacteria, such as: Planacoccus citreus, Escherichia coli and Salmonella enteritidis.

Based on the strains of L. plantarum, L. delbrueckii s/ sp.lactis 013 and $L$. casei $s / s p$. tolerans 290 nine variants of compositions were made and their biotechnological potential was studied. All the compositions were able to grow even at $0{ }^{\circ} \mathrm{C}$. The most stable was the starter made of $L$. delbrueckii s/sp. lactis $013+$ L. plantarum 12 at the ratio of $1: 2$, the growth rate of which at $5{ }^{\circ} \mathrm{C}$ was estimated as "exceptional". The lactic acid bacteria compositions significantly inhibited the growth of the indicator bacteria. The dimensions of the "no growth' areas for the bacteria isolated from meat ranged from 16 $\mathrm{mm}$ to $43 \mathrm{~mm}$ depending on the indicator strain and composition. The most sensitive bacteria from the collection ones were the grampositive cocci $P$. citreus and M. luteus, for which the "no growth" area dimensions, depending on the composition, ranged from $34 \mathrm{~mm}$ to $42 \mathrm{~mm}$ and from $28 \mathrm{~mm}$ to $40 \mathrm{~mm}$, respectively.

Conclusions. The results show an increase in the biotech activity of the lactic acid bacteria in the compositions. The most promising for testing in an industrial environment is a composition of L. delbrueckii s/sp. lactis $013+$ L. plantarum 12 at the ratio of 1:2. 


\section{Introduction}

Providing the population with the high-grade whole food, meat and meat products in particular, is one of the priorities of the contemporary food industry. High nutrition and biological value of meat, the possibility to get a thousand of finished products different in the form, taste, flavor, succulence, color and consistency are determined by the heterogeneity of its structure, composition and high variability of its properties $[1,2]$.

Since meat is a favorable breeding ground, there is a high risk of the development, reproduction and accumulation of microorganisms in it $[5,6]$. The sources of the microbial contamination can be exogenous and endogenous.

To maintain quality, prevent development of deficiencies and extend the storage life of meat, various types of processing are offered. One of the current trends is the biotechnological methods aimed at modification and optimization of the functional and technological properties of the raw meat, and improvement of its quality characteristics during storage [7, 8, 9]. For this purpose, use of the lactic acid bacteria seems most promising, in particular, the Lactobacillus genus bacteria, producing organic acids, enzymes and other bioactive substances which promote the antagonistic properties in respect of the undesirable raw meat microbiota [10]. There are works of the domestic and foreign scientists devoted to search for the promising lactic acid bacteria and making compositions (consortia) based on them, the so called "bacterial starters" [11, 12, 13]. However, in general they relate to use of starters in manufacture of the meat products. There are few works related to use of the microorganism cultures to improve the raw meat quality and extend its storage period. The issue of choice of the bacterial composition and its influence on the contaminating microbiota development is still vita [14].

Therefore, the purpose of this work is selection of the lactic acid bacteria strains and making the compositions suitable for bioprotection of the raw meat (having antagonistic activity to the collection bacteria strains and those isolated from the raw meat).

\section{Matherials and methods}

We studied 8 collection lactic acid bacteria strains (Lactobacillus plantarum 12, 1005, L. delbrueckii s/sp. lactis 013, L. acidophilus 147, L. gasseri 149, L. casei s/sp. tolerans 187 and 290, L. casei s/sp. rhamnosus 283); the lactic acid bacteria compositions made; the indicator bacteria isolated from the raw material (Bacillus sp. 1, 2, 3 Kurthia sp., Planacoccus sp. 1, 2, Micrococcus sp. 1, 2, Sarcina sp., Staphylococcus sp.) and the collection strains of saprophytic (Planacoccus citreus, Micrococcus luteus, Bacillus subtilis, Bacillus cereus, Bacillus megaterium), opportunistic pathogenic (Staphylococcus aureus, Escherichia coli, Proteus vulgaris) and pathogenic (Salmonella enteritidis) bacteria.

To activate the lactic acid bacteria strains, inoculation to the liquid MRS medium enriched with $5 \%$ glucose solution was carried out.

Resistance of the lactic acid bacteria and their compositions to salt was determined by growth rate in the culture medium (MRS-broth) with introduction of sodium chloride at the concentrations of $2.5 ; 5.0 ; 7.5$ and $10.0 \%$.

Growth rate at the low above-zero temperatures was measured at $0,5,10,15,20$ and 25 ${ }^{\circ} \mathrm{C}$ for 14 days.

The antagonistic activity was determined by the well-diffusion method. As the indicator bacteria strains, we used Bacillus sp. 1, 2, 3, Kurthia sp., Planacoccus sp. 1, 2, Micrococcus sp. 1, 2, Sarcina sp., Staphylococcus sp., isolated from the raw meat and $P$. 
citreus, M. luteus, B. subtilis, B. cereus, B. megaterium, S. aureus, E. coli, P. vulgaris and $S$. enteritidis as the collection ones. In the experiment, we used the daily broth cultures: the lactic acid bacteria were grown in the MRS-broth, and the indicator bacteria - in a nutrient broth. The results were taken in 24 hours by measuring the delay and growth inhibition areas for the indicator microorganisms. When determining the antagonistic activity, only the cases of complete indicator organism growth inhibition were taken into account. If the size of a "no growth" area ranged from $10 \mathrm{~mm}$ to $20 \mathrm{~mm}$, the degree of activity was considered average, if it was greater than $20 \mathrm{~mm}$ - high.

\section{Results and discussion}

The biological methods to treat the raw meat for extending its storage life are based on use of the bacterial starters consisting of the specially selected species and strains of microorganisms, in particular, the lactic acid bacteria of Lactobacillus genus. In selection of the lactic acid bacteria strains to make starters with a high biotechnological potential, their value measures included: halotolerance, thermo-resistance and symbiotic nature of the relationship between the cultures and antagonistic activity against the opportunistic pathogenic and pathogenic microbiota $[3,9,11]$.

In this connection, at the first stage of work we studied the resistance of 8 collection lactic acid bacteria strains to salt and low above-zero temperatures. The results showed that adding $\mathrm{NaCl}$ to the culture medium at the concentrations of 2.5 to $7.5 \%$ did not influence the bacteria growth, and their growth rate was estimated as "exceptional". A $10.0 \%$ salt concentration in the culture medium inhibited the growth of the strains under study. With such $\mathrm{NaCl}$ content, only two strains (L. plantarum 12 and 1005) showed high growth rate and two strains (L. delbrueckii s/sp. lactis 013 and L. casei s/sp. tolerans 290) - the average one (Table 1).

Table 1

Resistance of the lactic acid bacteria to $\mathrm{NaCl}$ and temperature

\begin{tabular}{|l|c|c|}
\hline \multirow{2}{*}{ Strain } & \multicolumn{2}{|c|}{ Growth rate at } \\
\cline { 2 - 3 } & $\mathbf{1 0 . 0} \%$ of $\mathbf{~ a C l}$ & $\mathbf{5}^{\mathbf{0}} \mathbf{C}$ \\
\hline L. plantarum 12 & high & high \\
\hline L. delbrueckii s/sp. lactis 013 & average & high \\
\hline L. acidophilus 147 & average & high \\
\hline L. gasseri 149 & low & low \\
\hline L. casei s/sp. tolerans 187 & low & high \\
\hline L. casei s/sp. rhamnosus 283 & low & average \\
\hline L. casei s/sp. tolerans 290 & average & high \\
\hline L. plantarum 1005 & high & average \\
\hline
\end{tabular}

Similar studies with respect to the growth potency at the temperature ranged from $5{ }^{\circ} \mathrm{C}$ to $25{ }^{\circ} \mathrm{C}$ showed that most significantly the lactic acid bacteria growth slowed at $5^{\circ} \mathrm{C}$. The obtained results are listed in Table 1 showing the growth rate of the selected strains at the lowest of the above temperatures. Such strains as L. plantarum, L. delbrueckii s/sp. lactis 013, L. acidophilus 147, L. casei s/sp. tolerans 187 and 290 appeared to be thermoresistant. 
Determination of the lactic acid bacteria antagonistic properties showed that they were active against both, the strains isolated from the raw meat and the collection ones. At that, growth of some indicator bacteria was slowed down only, while that of others - completely inhibited. Thus, all strains of the lactic acid bacteria studied only slowed down the growth of Bacillus sp. 1, isolated from the raw meat, and the collection B. subtilis and B. cereus; while the growth of Planacoccus sp. 2 (from meat), Micrococcus sp. 2 (from meat) and $S$. enteritidis (from collection) was inhibited completely. It should be noted that size of the "stasis" and "no growth" areas was different and depended both, from strain of the lactic acid bacteria, and an indicator microorganism. The bacteria isolated from the raw meat and the collection bacteria appeared to be most sensitive to the metabolites produced by the three lactic acid bacteria strains: L. casei s/sp. tolerans 290, L. delbrueckii s/sp. lactis 013 and $L$. plantarum 12 . The results of determination of the antagonistic activity of the lactic acid bacteria are shown in Table 2.

Table 2

Antagonistic activity of the lactic acid bacteria strains

\begin{tabular}{|c|c|c|c|c|c|c|c|c|c|c|}
\hline \multirow{3}{*}{ 泀 } & \multicolumn{10}{|c|}{ Size of delay and lack of growth areas of the indicator bacteria (mm) } \\
\hline & \multicolumn{10}{|c|}{ isolated from raw meat } \\
\hline & 1 & 2 & 3 & 4 & 5 & & $\mid$ & 8 & 9 & 10 \\
\hline A & $25^{\wedge}$ & $26^{\wedge}$ & $23 *$ & $26^{*}$ & $25^{*}$ & & 2 & $24 *$ & $23^{*}$ & $30^{*}$ \\
\hline $\mathrm{B}$ & $25^{\wedge}$ & $28^{\wedge}$ & $29 *$ & $30^{*}$ & $24 *$ & & 2 & $31 *$ & $30 *$ & $40^{*}$ \\
\hline $\mathrm{C}$ & $25^{\wedge}$ & $20 *$ & $28 *$ & $32 *$ & $20 *$ & & 2 & $23 *$ & $45^{*}$ & $41 *$ \\
\hline \multirow{2}{*}{ 䔍 } & \multicolumn{10}{|c|}{ collection } \\
\hline & 11 & 12 & 13 & 12 & & & 16 & 17 & 18 & 19 \\
\hline $\mathrm{A}$ & $27 *$ & $40^{*}$ & $25^{*}$ & 35 & & & $29 *$ & $23^{\wedge}$ & $26^{\wedge}$ & $30^{\wedge}$ \\
\hline B & $29 *$ & - & $23^{*}$ & 27 & & & $24^{*}$ & $22^{\wedge}$ & $24^{\wedge}$ & $40 *$ \\
\hline $\mathrm{B}$ & $44^{*}$ & $34 *$ & $24^{\wedge}$ & 26 & & & $28 *$ & $24^{\wedge}$ & $34^{\wedge}$ & $25^{\wedge}$ \\
\hline
\end{tabular}

Note: “^” - stasis; “*”- no growth; “-" - no effect.

A - L. plantarum 12; B - L. delbrueckii s/sp. lactis 013; C - L. casei s/sp. tolerans 290.

1 - Bacillus sp. 1; 2 -Bacillus sp. 2; 3 -Bacillus sp. 3; 4 -Kurthia sp.; 5 - Planacoccus sp. 1; 6-Planacoccus sp. 2; 7 - Micrococcus sp. 1; 8-Micrococcus sp. 2; 9 - Sarcina sp.; 10 - Staphylococcus sp.; 11 - Planacoccus citreus; 12 - Micrococcus luteus;

13 - Staphylococcus aureus; 14 - Escherichia coli; 15 - Proteus vulgaris; 16 - Salmonella enteritidis; 17 -Bacillus subtilis; 18 -Bacillus cereus; 19 -Bacillus megaterium.

To estimate the antagonist activity of $L$. casei s/sp. tolerans 290, L. delbrueckii $s / s p$. lactis 013 and L. plantarum 12 we considered only the cases of complete indicator organism growth inhibition (lack of growth). As seen from the data in Table. 3, the lactic acid bacteria strains isolated from the raw meat and the collection bacteria showed high antagonistic activity, therewith, the size of the "no growth" areas for the indicator bacteria growth was different (Table 3). 
Antagonistic activity of the lactic acid bacteria strains

\begin{tabular}{|c|c|c|c|c|c|c|c|c|c|c|c|c|c|c|c|c|c|c|c|}
\hline \multirow{3}{*}{ 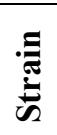 } & \multicolumn{19}{|c|}{ Activity in relation to the indicator bacteria } \\
\hline & \multicolumn{10}{|c|}{ isolated from raw meat } & \multicolumn{9}{|c|}{ collection } \\
\hline & 1 & 2 & 3 & 4 & 5 & 6 & 7 & 8 & 9 & 10 & 11 & 12 & 13 & 14 & 15 & 16 & 17 & 18 & 19 \\
\hline A & $\mathrm{D}$ & $\mathrm{D}$ & $\mathrm{H}$ & $\mathrm{H}$ & $\mathrm{H}$ & $\mathrm{H}$ & $\mathrm{D}$ & $\mathrm{H}$ & $\mathrm{H}$ & $\mathrm{H}$ & $\mathrm{H}$ & $\mathrm{H}$ & $\mathrm{H}$ & $\mathrm{H}$ & $\mathrm{D}$ & $\mathrm{H}$ & $\mathrm{D}$ & $\mathrm{D}$ & $\mathrm{D}$ \\
\hline B & $\mathrm{D}$ & D & $\mathrm{H}$ & $\mathrm{H}$ & $\mathrm{H}$ & $\mathrm{H}$ & $\mathrm{H}$ & $\mathrm{H}$ & $\mathrm{H}$ & $\mathrm{H}$ & $\mathrm{H}$ & - & $\mathrm{H}$ & $\mathrm{H}$ & - & $\mathrm{H}$ & D & D & $\mathrm{H}$ \\
\hline $\mathrm{C}$ & $\mathrm{D}$ & $\mathrm{A}$ & $\mathrm{H}$ & $\mathrm{H}$ & $\mathrm{A}$ & $\mathrm{H}$ & $\mathrm{D}$ & $\mathrm{H}$ & $\mathrm{H}$ & $\mathrm{H}$ & $\mathrm{H}$ & $\mathrm{H}$ & $\mathrm{D}$ & $\mathrm{H}$ & $\mathrm{D}$ & $\mathrm{H}$ & $\mathrm{D}$ & $\mathrm{D}$ & $\mathrm{D}$ \\
\hline
\end{tabular}

Note: "D" - stasis; "H" - high activity; "A" - average activity; “-" - no effect. A - L. plantarum 12; B - L. delbrueckii s/sp. lactis 013; C - L. casei s/sp. tolerans 290. 1 - Bacillus sp. 1; 2 -Bacillus sp. 2; 3 -Bacillus sp. 3; 4 -Kurthia sp.; 5 - Planacoccus sp. 1; 6-Planacoccus sp. 2; 7 -Micrococcus sp. 1; 8-Micrococcus sp. 2; 9 -Sarcina sp.; 10 - Staphylococcus sp.; 11 - Planacoccus citreus; 12 -Micrococcus luteus; 13 - Staphylococcus aureus; 14 - Escherichia coli; 15 - Proteus vulgaris; 16 - Salmonella enteritidis; 17 -Bacillus subtilis; 18 -Bacillus cereus; 19 -Bacillus megaterium.

It is known that the starter multispecies are more active and resistant to the adverse environmental factors compared to the starters, made on the basis of certain cultures $[5,12$, 13]. Therefore, considering the obtained results, three strains of the lactic acid bacteria $-L$. casei s / sp. tolerans 290, L. delbrueckii s / sp. lactis 013 and L. plantarum 12 - were chosen to make compositions (starters).

One of the important criteria for combining individual species into a multispecies starter is the compatibility of species and strains, i.e., first of all, they must not be reciprocal antagonists. The research of the intrageneric antagonism of the selected lactic acid bacteria showed no reciprocal growth inhibition.

So, to pursue further studies, we made 9 variants of the lactic acid bacteria compositions consisting of two lactic acid bacteria one-to-one: $(1-$ L. plantarum $12+L$. casei s/sp. tolerans $290 ; 2-$ L. plantarum $12+$ L. delbrueckii s/sp. lactis $013 ; 3-$ L. casei s/sp. tolerans $290+$ L. delbrueckii s/sp. lactis 013) и 1:2 (4-L. plantarum $12+$ L. casei s/sp. tolerans 290; 5 - L. plantarum $12+$ L. delbrueckii s/sp. lactis $013 ; 6-$ L. casei s/sp. tolerans $290+$ L. plantarum 12; 7 - L. delbrueckii s/sp. lactis $013+$ L. plantarum $12 ; 8-L$. casei s/sp. tolerans $290+$ L. delbrueckii s/sp. lactis $013 ; 9-$ L. delbrueckii s/sp. lactis $013+$ L. casei s/sp. tolerans 290) (Table 4).

Using starters in the meat industry, one shall take into account the temperature modes of production and storage of the raw meat.

Study of the growth rate of the lactic acid bacteria compositions at the temperature ranged from $0^{\circ} \mathrm{C}$ to $25^{\circ} \mathrm{C}$ showed that the effect of temperature on individual compositions was similar (Table 5). It was noted that the temperature of $10^{\circ} \mathrm{C}$ and $15^{\circ} \mathrm{C}$ had no effect on growth of the starters studied (growth rate was estimated as "very high"), at $5^{\circ} \mathrm{C}$ most starters (samples No. 2, 3, 4, 5 and 9) were characterized by "average" growth and development rate. Moreover, composition No. 7 consisting of $L$. delbrueckii s/sp. lactis 013 + L. plantarum 12 at the ratio of 1:2 appeared to be so resistant to the above temperature, that its growth was described as "exceptional". 
Combinations of the lactic acid bacteria compositions

\begin{tabular}{|c|c|c|c|c|c|c|}
\hline \multirow[t]{3}{*}{ Strain } & \multicolumn{6}{|c|}{ Combinations } \\
\hline & \multicolumn{3}{|c|}{ 1:1 } & \multicolumn{3}{|c|}{$1: 2$} \\
\hline & 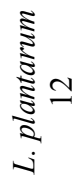 & 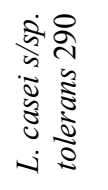 & 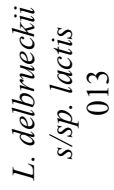 & 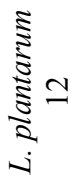 & 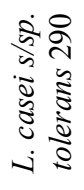 & 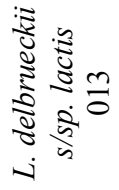 \\
\hline L. plantarum 12 & - & $+1: 1$ & $1: 1$ & - & $1: 2$ & $1: 2$ \\
\hline L. casei s/sp. tolerans 290 & - & - & $1: 1$ & $1: 2$ & - & $1: 2$ \\
\hline L. delbrueckii s/sp. lactis 013 & - & - & - & $1: 2$ & $1: 2$ & - \\
\hline
\end{tabular}

Using starters in the meat industry, one shall take into account the temperature modes of production and storage of the raw meat.

Study of the growth rate of the lactic acid bacteria compositions at the temperature ranged from $0^{\circ} \mathrm{C}$ to $25^{\circ} \mathrm{C}$ showed that the effect of temperature on individual compositions was similar (Table 5). It was noted that the temperature of $10^{\circ} \mathrm{C}$ and $15^{\circ} \mathrm{C}$ had no effect on growth of the starters studied (growth rate was estimated as "very high"), at $5^{\circ} \mathrm{C}$ most starters (samples No. 2, 3, 4, 5 and 9) were characterized by "average" growth and development rate. Moreover, composition No. 7 consisting of L. delbrueckii s/sp. lactis 013 + L. plantarum 12 at the ratio of 1:2 appeared to be so resistant to the above temperature, that its growth was described as "exceptional".

Table 5

Growth rate of the lactic acid bacteria compositions at different temperatures

\begin{tabular}{|c|c|c|c|c|}
\hline $\begin{array}{c}\text { Number } \\
\text { of composition }\end{array}$ & $\mathbf{0}^{\circ} \mathbf{C}$ & $\mathbf{5}^{\circ} \mathbf{C}$ & $\mathbf{1 0}^{\circ} \mathbf{C}$ & $\mathbf{1 5}^{\circ} \mathbf{C}$ \\
\hline 1 & + & +++ & ++++ & ++++ \\
\hline 2 & + & ++ & ++++ & ++++ \\
\hline 3 & + & ++ & ++++ & ++++ \\
\hline 4 & + & ++ & ++++ & ++++ \\
\hline 5 & + & ++ & ++++ & ++++ \\
\hline 6 & + & +++ & ++++ & ++++ \\
\hline 7 & + & ++++ & ++++ & ++++ \\
\hline 8 & + & +++ & ++++ & ++++ \\
\hline 9 & + & ++ & ++++ & ++++ \\
\hline
\end{tabular}

Note: “++++" - exceptional growth rate, “+++" - high, “++" - average, “+” - low.

It should be noted that even at $0^{\circ} \mathrm{C}$ weak growth of all the lactic acid bacteria compositions was observed. Comparing the results obtained in the study of the growth rate at low above-zero temperatures of individual lactic acid bacteria strains (Table 1) and their compositions (Table 5) one can assume that combinations of cultures in the starters increases their thermo-resistance.

One of the most important criteria put forward both, to individual strains of the lactic acid bacteria, and the starters, made of them, is the antagonistic activity [11]. Considering 
that the strains of L. casei s/sp. tolerans 290, L. delbrueckii s/sp. lactis 013 and $L$. plantarum 12 taken individually were active antagonists to the indicator bacteria (both, the collection and isolated from the raw meat) (Tables 2,3), and in view of the existing requirements, it was appropriate to determine whether the starter's composition and the ratio of the lactic acid bacteria in it influence the antagonistic properties. The results are presented in Table 6 .

Table 6

Antagonistic activity of the lactic acid bacteria compositions

\begin{tabular}{|c|c|c|c|c|c|c|c|c|c|c|}
\hline \multirow{3}{*}{ 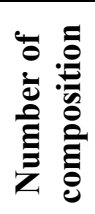 } & \multicolumn{10}{|c|}{ Size of delay and lack of growth areas of the indicator bacteria (mm) } \\
\hline & \multicolumn{10}{|c|}{ isolated from raw meat } \\
\hline & 1 & 2 & 3 & 4 & 5 & 6 & 7 & 8 & 9 & 10 \\
\hline 1 & $26^{\wedge}$ & $22 *$ & $30 *$ & $31 *$ & $21 *$ & $30^{*}$ & $22 *$ & $40^{*}$ & $32 *$ & $34^{*}$ \\
\hline 2 & $27^{\wedge}$ & $23^{*}$ & $27 *$ & $31 *$ & $28 *$ & $28 *$ & $27^{*}$ & $42 *$ & $31 *$ & $39 *$ \\
\hline 3 & $25^{\wedge}$ & $21 *$ & $29 *$ & $32 *$ & $25 *$ & $28 *$ & $29 *$ & $42 *$ & $34^{*}$ & $36^{*}$ \\
\hline 4 & $25^{\wedge}$ & $22 *$ & $32 *$ & $30 *$ & $25 *$ & $29 *$ & $25^{*}$ & $40^{*}$ & $32 *$ & $36^{*}$ \\
\hline 5 & $22^{\wedge}$ & $16^{*}$ & $30^{*}$ & $27 *$ & $26^{*}$ & $38 *$ & $27^{*}$ & $39 *$ & $32 *$ & $43^{*}$ \\
\hline 6 & $26^{\wedge}$ & $21 *$ & $26^{*}$ & $29 *$ & $25 *$ & $26^{*}$ & $26^{*}$ & $34^{*}$ & $34^{*}$ & $43^{*}$ \\
\hline 7 & $29^{\wedge}$ & $21 *$ & $32 *$ & $30 *$ & $27 *$ & $25^{*}$ & $27 *$ & $39 *$ & $32 *$ & $43 *$ \\
\hline 8 & $24^{\wedge}$ & $23 *$ & $28 *$ & $30 *$ & $25 *$ & $26^{*}$ & $27^{*}$ & $33 *$ & $35^{*}$ & $40^{*}$ \\
\hline 9 & $26^{\wedge}$ & $21 *$ & $30 *$ & $31 *$ & $27 *$ & $27^{*}$ & $27^{*}$ & $34^{*}$ & $34^{*}$ & $31^{*}$ \\
\hline
\end{tabular}

\begin{tabular}{|c|c|c|c|c|c|c|c|c|c|}
\hline \multirow{3}{*}{ 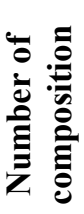 } & \multicolumn{9}{|c|}{ Size of delay and lack of growth areas of the indicator bacteria (mm) } \\
\hline & \multicolumn{9}{|c|}{ collection } \\
\hline & 11 & 12 & 13 & 14 & 15 & 16 & 17 & 18 & 19 \\
\hline 1 & $34 *$ & $34 *$ & $21 *$ & $27 *$ & - & $24 *$ & $25 *$ & $24 *$ & $26^{*}$ \\
\hline 2 & $40^{*}$ & $40 *$ & $26^{*}$ & $38 *$ & - & $23 *$ & $26^{\wedge}$ & $21 *$ & $29 *$ \\
\hline 3 & $42 *$ & $42 *$ & $21 *$ & $32 *$ & - & $21 *$ & $24^{\wedge}$ & $23 *$ & $25^{*}$ \\
\hline 4 & $40 *$ & $40^{*}$ & $23 *$ & $30 *$ & - & $22 *$ & $28^{*}$ & $24 *$ & $23 *$ \\
\hline 5 & $40 *$ & $40^{*}$ & $25^{*}$ & $28 *$ & - & $24 *$ & $27^{\wedge}$ & $28 *$ & $27 *$ \\
\hline 6 & $37 *$ & $37^{*}$ & $23 *$ & $34 *$ & $24^{\wedge}$ & $25^{*}$ & $27^{\wedge}$ & $23 *$ & $24^{*}$ \\
\hline 7 & $42 *$ & $42 *$ & $26^{*}$ & $37^{*}$ & $23 *$ & $29 *$ & $29^{\wedge}$ & $29 *$ & $27 *$ \\
\hline 8 & $38^{*}$ & $38^{*}$ & $19 *$ & $26^{*}$ & $23 *$ & $23^{*}$ & $26^{\wedge}$ & $25^{*}$ & $22^{\wedge}$ \\
\hline 9 & $40 *$ & $40 *$ & $20 *$ & $24 *$ & $19^{\wedge}$ & $23 *$ & $24^{\wedge}$ & $26^{\wedge}$ & $24^{\wedge}$ \\
\hline
\end{tabular}

Note: “^” - stasis; “*” - no growth; “-”- no effect.

1 - Bacillus sp. 1; 2 - Bacillus sp. 2; 3 - Bacillus sp. 3; 4 - Kurthia sp.; 5 Planacoccus sp. 1;6-Planacoccus sp. 2; 7 -Micrococcus sp. 1;8-Micrococcus sp. 2; 9 - Sarcina sp.; 10 - Staphylococcus sp.; 11 - Planacoccus citreus; 12 - Micrococcus luteus; 13 - Staphylococcus aureus; 14 - Escherichia coli; 15 - Proteus vulgaris; 16 - Salmonella enteritidis; 17 -Bacillus subtilis; 18 -Bacillus cereus; 19 -Bacillus megaterium 
Growth of the bacteria isolated from meat (except for Bacillus $s p$. 1) was significantly inhibited by metabolites. The size of the "no growth" areas for the indicator bacteria ranged from $16 \mathrm{~mm}$ (determined for Bacillus sp. 2 under the effect of starter No. 5) to $43 \mathrm{~mm}$ (determined for Staphylococcus sp. in the presence of starters No. 5,6 and 7). The most resistant strain was Bacillus sp. 1, the growth of which by all the starters was delayed only.

Table 7

Degree of antagonistic activity of the lactic acid bacteria compositions

\begin{tabular}{|c|c|c|c|c|c|c|c|c|c|c|}
\hline \multirow{3}{*}{ 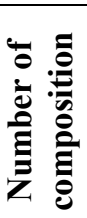 } & \multicolumn{10}{|c|}{ Size of delay and lack of growth areas of the indicator bacteria (mm) } \\
\hline & \multicolumn{10}{|c|}{ isolated from raw meat } \\
\hline & 1 & 2 & 3 & 4 & 5 & 6 & 7 & 8 & 9 & 10 \\
\hline 1 & $\mathrm{D}$ & $\mathrm{H}$ & $\mathrm{H}$ & $\mathrm{H}$ & $\mathrm{H}$ & $\mathrm{H}$ & $\mathrm{H}$ & $\mathrm{H}$ & $\mathrm{H}$ & $\mathrm{H}$ \\
\hline 2 & $\mathrm{D}$ & $\mathrm{H}$ & $\mathrm{H}$ & $\mathrm{H}$ & $\mathrm{H}$ & $\mathrm{H}$ & $\mathrm{H}$ & $\mathrm{H}$ & $\mathrm{H}$ & $\mathrm{H}$ \\
\hline 3 & $\mathrm{D}$ & $\mathrm{H}$ & $\mathrm{H}$ & $\mathrm{H}$ & $\mathrm{H}$ & $\mathrm{H}$ & $\mathrm{H}$ & $\mathrm{H}$ & $\mathrm{H}$ & $\mathrm{H}$ \\
\hline 4 & $\mathrm{D}$ & $\mathrm{H}$ & $\mathrm{H}$ & $\mathrm{H}$ & $\mathrm{H}$ & $\mathrm{H}$ & $\mathrm{H}$ & $\mathrm{H}$ & $\mathrm{H}$ & $\mathrm{H}$ \\
\hline 5 & $\mathrm{D}$ & $\mathrm{A}$ & $\mathrm{H}$ & $\mathrm{H}$ & $\mathrm{H}$ & $\mathrm{H}$ & $\mathrm{H}$ & $\mathrm{H}$ & $\mathrm{H}$ & $\mathrm{H}$ \\
\hline 6 & $\mathrm{D}$ & $\mathrm{H}$ & $\mathrm{H}$ & $\mathrm{H}$ & $\mathrm{H}$ & $\mathrm{H}$ & $\mathrm{H}$ & $\mathrm{H}$ & $\mathrm{H}$ & $\mathrm{H}$ \\
\hline 7 & $\mathrm{D}$ & $\mathrm{H}$ & $\mathrm{H}$ & $\mathrm{H}$ & $\mathrm{H}$ & $\mathrm{H}$ & $\mathrm{H}$ & $\mathrm{H}$ & $\mathrm{H}$ & $\mathrm{H}$ \\
\hline 8 & $\mathrm{D}$ & $\mathrm{H}$ & $\mathrm{H}$ & $\mathrm{H}$ & $\mathrm{H}$ & $\mathrm{H}$ & $\mathrm{H}$ & $\mathrm{H}$ & $\mathrm{H}$ & $\mathrm{H}$ \\
\hline 9 & $\mathrm{D}$ & $\mathrm{H}$ & $\mathrm{H}$ & $\mathrm{H}$ & $\mathrm{H}$ & $\mathrm{H}$ & $\mathrm{H}$ & $\mathrm{H}$ & $\mathrm{H}$ & $\mathrm{H}$ \\
\hline
\end{tabular}

\begin{tabular}{|c|c|c|c|c|c|c|c|c|c|}
\hline \multirow{3}{*}{ 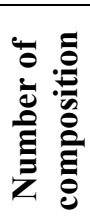 } & \multicolumn{9}{|c|}{ Size of delay and lack of growth areas of the indicator bacteria (mm) } \\
\hline & \multicolumn{9}{|c|}{ collection } \\
\hline & 11 & 12 & 13 & 14 & 15 & 16 & 17 & 18 & 19 \\
\hline 1 & $\mathrm{H}$ & $\mathrm{H}$ & $\mathrm{H}$ & $\mathrm{H}$ & - & $\mathrm{H}$ & $\mathrm{H}$ & $\mathrm{H}$ & $\mathrm{H}$ \\
\hline 2 & $\mathrm{H}$ & $\mathrm{H}$ & $\mathrm{H}$ & $\mathrm{H}$ & - & $\mathrm{H}$ & $\mathrm{D}$ & $\mathrm{H}$ & $\mathrm{H}$ \\
\hline 3 & $\mathrm{H}$ & $\mathrm{H}$ & $\mathrm{H}$ & $\mathrm{H}$ & - & $\mathrm{H}$ & $\mathrm{D}$ & $\mathrm{H}$ & $\mathrm{H}$ \\
\hline 4 & $\mathrm{H}$ & $\mathrm{H}$ & $\mathrm{H}$ & $\mathrm{H}$ & - & $\mathrm{H}$ & $\mathrm{H}$ & $\mathrm{H}$ & $\mathrm{H}$ \\
\hline 5 & $\mathrm{H}$ & $\mathrm{H}$ & $\mathrm{H}$ & $\mathrm{H}$ & - & $\mathrm{H}$ & $\mathrm{D}$ & $\mathrm{H}$ & $\mathrm{H}$ \\
\hline 6 & $\mathrm{H}$ & $\mathrm{H}$ & $\mathrm{H}$ & $\mathrm{H}$ & $\mathrm{D}$ & $\mathrm{H}$ & $\mathrm{D}$ & $\mathrm{H}$ & $\mathrm{H}$ \\
\hline 7 & $\mathrm{H}$ & $\mathrm{H}$ & $\mathrm{H}$ & $\mathrm{H}$ & $\mathrm{H}$ & $\mathrm{H}$ & $\mathrm{D}$ & $\mathrm{H}$ & $\mathrm{H}$ \\
\hline 8 & $\mathrm{H}$ & $\mathrm{H}$ & A & $\mathrm{H}$ & $\mathrm{H}$ & $\mathrm{H}$ & $\mathrm{D}$ & $\mathrm{H}$ & $\mathrm{D}$ \\
\hline 9 & $\mathrm{H}$ & $\mathrm{H}$ & $\mathrm{A}$ & $\mathrm{H}$ & $\mathrm{D}$ & $\mathrm{H}$ & $\mathrm{D}$ & $\mathrm{D}$ & $\mathrm{D}$ \\
\hline
\end{tabular}

Note: "D" - stasis; "H" - high activity; "A" - average activity; "-." - no effect

1 - Bacillus sp. 1; 2 -Bacillus sp. 2; 3 -Bacillus sp. 3; 4 -Kurthia sp.; 5 - Planacoccus sp. 1;6-Planacoccus sp. 2; 7 -Micrococcus sp. 1;8-Micrococcus sp. 2; 9 - Sarcina sp.; 10 - Staphylococcus sp.; 11 - Planacoccus citreus; 12 - Micrococcus luteus; 13 Staphylococcus aureus; 14 - Escherichia coli; 15 - Proteus vulgaris; 16 - Salmonella enteritidis; 17 -Bacillus subtilis; 18 -Bacillus cereus; 19 -Bacillus megaterium. 
From the collection bacteria, the most sensitive to metabolites of the compositions were the gram positive cocci P. citreus and M. luteus, the size of the "no growth" areas of which, depending on the composition, ranged from $34 \mathrm{~mm}$ to $42 \mathrm{~mm}$ and from $28 \mathrm{~mm}$ to $40 \mathrm{~mm}$, respectively. The least exposed to the starter effect were olm ( $P$. vulgaris), probably, due to a short lag-phase of this microorganism, and hay bacillus (B. subtilis), may be due to formation of resistance to the adverse conditions.

The most active was composition No. 7, in the presence of which the growth of almost every indicator bacteria was inhibited completely, and its activity was rated as "high".

As can be seen from the data presented, the lactic acid bacteria compositions inhibited the growth and development of the indicator bacteria. The degree of the antagonistic activity of the compositions under study to most indicator organisms was high (Table 7), while the sensitivity of individual, both the collection, and isolated from the raw meat microorganisms, was determined by a specific starter.

Comparing the data obtained in studying the antagonistic activity of individual lactic acid bacteria strains and their compositions, in most cases we observed an increased activity of the latter, presumably, due to the synergy phenomenon, when the effect of the metabolites produced by bacteria in the starters exceeds the effect of each taken individually.

Thus, the results give evidence of promising starter use in the industry to extend the storage life of the meat and meat products. With a view to industrial testing, composition No. 7 has been selected, consisting of L. delbrueckii s/sp. lactis $013+$ L. plantarum 12 at the ratio of $1: 2$.

\section{Conclusions}

1. It is experimentally found that the strains of bacteria of Lactobacillus genus ( $L$. plantarum 12 and 1005, L. delbrueckii s/sp. lactis 013, L. acidophilus 147, L. gasseri 149, L. casei s/sp. tolerans 187 and 290, and L. casei s sp. rhamnosus 283) are haloand thermo-resistant, as well as antagonistically active against the bacteria isolated from the raw meat and the collection bacteria.

2. The choice of L. plantarum 12 , L. delbrueckii s/sp. lactis 013 and $L$. casei $s / s p$. tolerans 290 to make the lactic acid bacteria compositions is proved.

3. It is shown that the biotech activity of the lactic acid bacteria in the compositions increased.

4. It is determined that the composition of $L$. delbrueckii $s / s p$. lactis $013+L$. plantarum 12 in the ratio of $1: 2$ is the most promising for testing in the industrial environment.

\section{References}

1. Solovjova A.A., Zinina O.V., Rebezov M.B., Lakeeva M.L., Gavrilova E. V. (2013), Recent biotechnological solutions in the meat industry, Molodoy ucheny, 5, pp. 105107.

2. Zhang W., Xiao S., Samaraweera H., Lee E., Ahn D.U. (2010), Improving functional value of meat products, Meat Science, 86(1), pp.15-31.

3. Zhou G.H., Xu X.L., Liu Y. (2010), Preservation technologies for fresh meat: a review, Meat Science, 86(1), pp. 119-128. 
4. Kamarudheen N., George C., Priya C. L., Bhaskara Rao K. V. (2014), Biopreservation of meat by probiotic bacteria isolated from dairy products, Der. Pharmacia Lettre, 6(6), pp. 266-71.

5. Bondareva G.I. (2015), Studying the biotechnological properties of microbial consortium, International Experimental Education Magazine, 6, pp. 80-81.

6. Ananou S., Maqueda M., Martínez-Bueno M., Valdivia E. (2007), Biopreservation, an ecological approach to improve the safety and shelf-life of foods, Applied Microbiology, pp. 475-486.

7. Vermeiren L., Devlieghere F., Debevere J. (2004), Evaluation of meat born lactic acid bacteria as protective cultures for the biopreservation of cooked meat products, Int. $J$. Food Microbiol, 96(2), pp.149-164.

8. Solovjova A.A., Rebezov M.B., Zinina O.V. (2013), Influence of starter cultures on functional and technological properties and microbiological safety of minced meat, Actual biotechnology, 2(5), pp. 18-22.

9. Nesterenko A.A., Schkhalakhov D.S. (2014), Use of microbial consortia to process raw meat in sausage production, Molodoy ucheny, 13, pp. 71-75.

10. Teusink B., Bachmann H., Molenaar D. (2011), Systems Biology of Lactic Acid Bacteria: a Critical Review, Microb. Cell. Fact., suppl. 1, pp. 11.

11. Ammor M.S., Mayo B. (2007), Selection criteria for lactic acid bacteria to be used as functional starter cultures in dry sausage production: An update, Meat Science, 76(1), pp. 138-146.

12. Idrisova E.N., Petrova M.Z. (2012), Scheid complex additives - a choice for quality of smoked sausages, Mjasnoy ryad, 3(49), pp. 26-27.

13. Poltavskaya Yu.A., Rebezov M. B., Solovjova A.A., Tarasova I.V., Zinina O.V. (2014), Foreign experience in the use of starter cultures in the production of sausages, Molodoy ucheny, 10(69), pp. 192-194. 